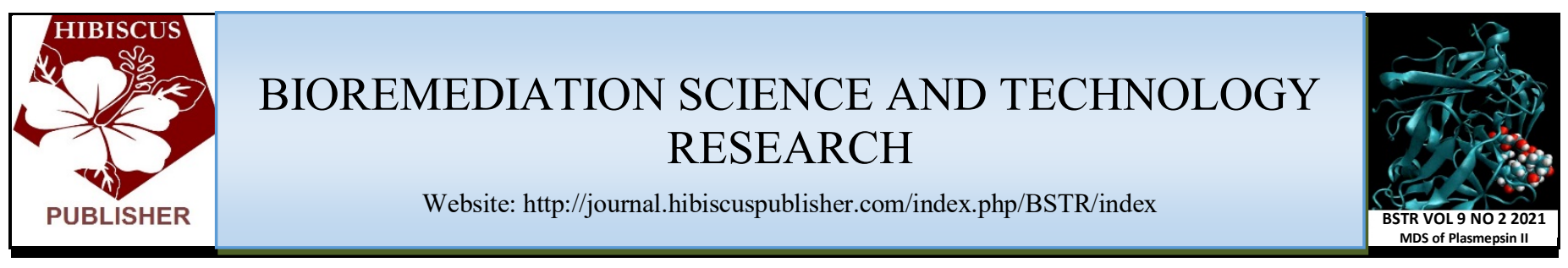

\title{
Characterization of Cypermethrin-degradation by a Novel Molybdenum-reducing Morganella sp. Isolated from Active Agricultural Land in Northwestern Nigeria
}

\author{
Mariam Lawan ${ }^{1}$, Hafeez Muhammad Yakasai ${ }^{1 *}$, Abba Babandi ${ }^{1}$, Salihu Ibrahim ${ }^{2}$, Dayyabu Shehu ${ }^{1}$, Murtala \\ $\mathrm{Ya}^{\prime} \mathrm{u}^{1}$ and Kamaluddeen Babagana ${ }^{1}$
}

${ }^{1}$ Department of Biochemistry, Faculty of Basic Medical Sciences, College of Health Science, Bayero University Kano, P.M. B 3011, Nigeria.

${ }^{2}$ Centre for Biotechnology Research, Bayero University Kano, P. M. B 3011, Nigeria.

\author{
*Corresponding author: \\ Dr. Hafeez Muhammad Yakasai, \\ Department of Biochemistry, \\ Faculty of Basic Medical Sciences, \\ College of Health Science, \\ Bayero University Kano, \\ P.M. B 3011, \\ Nigeria. \\ Email: hmyakasai.bch@buk.edu.ng
}

\section{HISTORY}

Received: $12^{\text {th }}$ Aug 2021

Received in revised form: 15th Nov 2021

Accepted: $15^{\text {th }}$ Dec 2021

\section{KEYWORDS}

Cypermethrin

Molybdenum-reducing

Pollutant

Morganella sp.

Bioremediation

\begin{abstract}
The increasing use of cypermethrin in agricultural fields, household and industrial applications for effective pest control had increased the global burden of the pollutant over the years. Consequently, there is an urgent need to devise techniques to eliminate this pollutant from the environment. A bacterium capable of degrading cypermethrin has been successfully screened and characterized. The bacterium was grown in a mineral salt medium (MSM) supplemented with cypermethrin as its sole carbon and energy source at an optimum $\mathrm{pH} 7.5$, temperature $40^{\circ} \mathrm{C}$, a carbon source concentration of $4 \mathrm{~g} / \mathrm{L}$, optimum incubation time of $24 \mathrm{~h}$ and an inoculum size of $400 \mu \mathrm{L}$. The potential of Morganella sp. to degrade cypermethrin makes it an important instrument for the degradation of cypermethrin. This knowledge may be useful for the optimization of environmental conditions for cypermethrin bioremediation and important for detoxification of cypermethrin polluted sites.
\end{abstract}

\section{INTRODUCTION}

Cypermethrin (a pyrethroid, $\mathrm{C}_{22} \mathrm{H}_{19} \mathrm{Cl}_{2} \mathrm{NO}_{3}$ ) is globally among the most widely synthetic insecticides used for agricultural and domestic purposes. Cypermethrin has been identified as one of the important constituents of pesticides associated with human health risks. It is extensively used in cotton, fruit, and vegetable crops as well as in animal health, home and garden pest control worldwide [1].

Cypermethrin has been reported to posse neurotoxicity, immunotoxicity and endocrine disruption effects [2]. In the natural environment hydrolysis of ester linkage is the principal degradation route and leads to the formation of 3 phenoxybenzoic acid (3-PBA) and cyclopropanecarboxylic acid derivatives [3]. Cypermethrin is readily absorbed through the soil surface due to its nonpolar nature, however, these metabolites are organic acids and are mobile in the soil [4]. Perhaps, 3-phenoxybenzoic acid (3-PBA) is also a potential toxicant and endocrine-disrupting chemical [5]. A current environmental concern is the contamination of the aquatic and terrestrial habitat due to the increased concentration of cypermethrin in the environment from agricultural field runoffs, manufacturing plants, leaching, accidental spills and other sources. Widespread occurrence of cypermethrin and 3-PBA has been reported in water bodies and sediments due to erosion and runoff from agricultural fields and nonagricultural applications [6]. Although there is quite a number of reports on the use of microorganisms for cypermethrin degradation, until present, there has been no report on the isolation cypermethrin-degrading bacteria from Northern Nigeria, even though the region is dominated by agricultural activities. This emphasizes the need to develop cost-effective strategies for the removal of toxic residues from the environment, hence the need to identify and characterize an endogenous microorganism with cypermethrin-degrading potential.

This research screens a collection of previously isolated molybdenum-reducing bacteria for cypermethrin-degrading potential, and hence characterize the degradation potential of the candidate isolate. 


\section{MATERIALS AND METHODS}

All media preparations (solid and broth) were made according to the methods of Yin et al. [7] and Ghani et al. [8] except otherwise stated. Cypermethrin $\left(\mathrm{C}_{22} \mathrm{H}_{19} \mathrm{Cl}_{2} \mathrm{NO}_{3}\right)$ of analytical grade was obtained from Chemet Wets \& Flows Pvt. Ltd. Ahmedabad, Gujarat, India.

\section{Screening of cypermethrin-degrading bacteria MSM Agar Preparation}

A total of seven (7) previously isolated molybdenum-reducing bacteria, were screened for their potential to degrade cypermethrin (pyrethroid). The bacterial isolates were inoculated on agar plates containing mineral salt medium (MSM) supplemented with $1000 \mathrm{mg} / \mathrm{L}$ cypermethrin. This medium was prepared by dissolving into a liter of distilled water $(\mathrm{g} / \mathrm{L}): 1.0$ $\mathrm{NH}_{4} \mathrm{NO}_{3}, 1.0 \mathrm{NaCl}, 1.5 \mathrm{~K}_{2} \mathrm{HPO}_{4}, 0.5 \mathrm{KH}_{2} \mathrm{PO}_{4}, 0.2 \mathrm{MgSO}_{4} 7 \mathrm{H}_{2} \mathrm{O}$, 15 agar and adjusted to $\mathrm{pH} 7$ before autoclaving at $121^{\circ} \mathrm{C}, 115$ $\mathrm{kPa}$ for $15 \mathrm{~min}$. The cypermethrin (as sole carbon and energy source) was dissolved in distilled water and autoclaved separately and added to the medium afterwards. The molten medium was allowed to cool to about $50^{\circ} \mathrm{C}$ before pouring into sterile disposable Petri dishes. Each of the 7 isolates was aseptically inoculated into fresh plates, sealed with masking tapes and incubated at $37^{\circ} \mathrm{C}$ for $48 \mathrm{~h}$. After the required incubation, the colonies developed on the plates were examined using a colony counter. The plate with the highest growth was identified as cypermethrin resistant strain.

\section{Preparation of Resting Cells}

A single colony was inoculated using a sterile wire loop into a freshly prepared mineral salt medium broth $\mathrm{pH} 7$, supplemented with $1000 \mathrm{mg} / \mathrm{L}$ cypermethrin as the sole carbon source then incubated at $37^{\circ} \mathrm{C}$ for $48 \mathrm{~h}$. Following the required incubation, the cells were centrifuged at $10,000 \times \mathrm{g}$ for $20 \mathrm{~min}$ to get the pellet. The pellet was then suspended in a freshly prepared MSM without the carbon source and refrigerated for subsequent use.

\section{Characterization of Cypermethrin Resistant Bacterial Strain}

The growth of the bacterial strain was studied at different conditions such as $\mathrm{pH}$, temperature, inoculum size, substrate concentration, incubation time by measuring the optical density (absorbance) at $600 \mathrm{~nm}$ in a spectrophotometer.

\section{Effect of Incubation Time}

The best incubation time for the isolate was determined by inoculating $2 \%(\mathrm{v} / \mathrm{v})$ isolate $\left(\mathrm{OD}_{600} \mathrm{~nm}\right)$ into sterilized airtight bottles containing $10 \mathrm{ml}$ of mineral salt medium supplemented with $1000 \mathrm{mg} / \mathrm{L}$ cypermethrin (substrate and sole carbon source) dissolved in distilled water at $\mathrm{pH}$ 7. An aliquot from the culture medium was taken at time intervals up to $72 \mathrm{~h}$ to spectrophotometrically measure the bacterial growth at $600 \mathrm{~nm}$. Each assay was performed in triplicates for tests and control setup.

\section{Effect of Inoculum Size}

The effect of inoculum size was studied by varying the volume of inoculum from $50-800 \mu \mathrm{L}(0.5-8 \% \mathrm{v} / \mathrm{v})$ introduced into $10 \mathrm{~mL}$ MSM pH 7 and incubated at $37^{\circ} \mathrm{C}$. The growth of the isolate on cypermethrin at various inoculum sizes was ascertained by spectrophotometrically measuring the OD at $600 \mathrm{~nm}$.

\section{Effect of Substrate Concentration (Cypermethrin)}

The effect of cypermethrin concentrations (sole carbon source) on its degradation by this isolate was carried out by varying the concentrations from 1000 to $5000 \mathrm{mg} / \mathrm{L}$ in the MSM inoculated with $2 \%(\mathrm{v} / \mathrm{v})$ isolate $\left(\mathrm{OD}_{600} \mathrm{~nm}\right)$. The growth of the bacterium was studied by measuring the optical density (absorbance) at 600 $\mathrm{nm}$ using a spectrophotometer.

\section{Effect of pH}

In this study, the effect of $\mathrm{pH}$ was determined to ascertain the suitable optimum $\mathrm{pH}$ that supports cypermethrin degradation by this bacterium. The initial $\mathrm{pH}$ of the medium was adjusted to $\mathrm{pH}$ $5.5,6.0,6.5,7.0,7.5,8.0$ and 8.5 respectively using $3 \mathrm{M} \mathrm{NaOH}$ and $50 \%$ dilute $\mathrm{HCl}$ acid prior to autoclaving, after which the carbon source (cypermethrin) was then added. $\%(\mathrm{v} / \mathrm{v})$ inoculum $\left(\mathrm{OD}_{600} \mathrm{~nm}\right)$ was added and incubated at $37^{\circ} \mathrm{C}$ for $72 \mathrm{~h}$. The bacterial growth was observed by measuring the optical density at $600 \mathrm{~nm}$ spectrophotometrically.

\section{Effect of Temperature}

Temperature is an important parameter that affects the bacterial growth and degradation process. The effect of temperature on cypermethrin degradation by this isolate was determined at a range between 25 and $50^{\circ} \mathrm{C}$ in a cypermethrin containing MSM at $\mathrm{pH} 7$ inoculated with $2 \%(\mathrm{v} / \mathrm{v})$ and incubated $37^{\circ} \mathrm{C}$ for $72 \mathrm{~h}$. The resulting growth was observed by measuring the optical density (absorbance) at $600 \mathrm{~nm}$ spectrophotometrically.

\section{Effect of Interacting Heavy Metal on Cypermethrin Degradation}

The effect of heavy metals interaction with cypermethrin degradation was conducted to ascertain the possible inhibition of the process by these metals, which often occur as cocontaminants at the pollution site. A stock solution (100 ppm) of each metal $\mathrm{Ag}, \mathrm{Hg}, \mathrm{Zn}, \mathrm{Cu}, \mathrm{Fe}, \mathrm{Pb}$ was separately prepared and a final concentration of $1 \mathrm{ppm}$ was supplemented into MSM containing cypermethrin $(1000 \mathrm{mg} / \mathrm{L})$, at $\mathrm{pH} 7$ inoculated with $2 \%(\mathrm{v} / \mathrm{v})$ and incubated $37^{\circ} \mathrm{C}$ for $72 \mathrm{~h}$. The resulting growth was observed by measuring the optical density (absorbance) at 600 $\mathrm{nm}$ spectrophotometrically.

\section{Effect of Shaking}

The effect of aeration on bacterial cypermethrin degradation under agitating and static conditions was studied to determine the factors that enhance the remediation process using an orbital shaker at $160 \mathrm{rpm}$. The microbial growth was measured by taking the optical density (absorbance) at $600 \mathrm{~nm}$. All experiments were carried out in triplicate.

\section{Effect of Cypermethrin on Molybdate reduction}

In this experiment, the use of cypermethrin as an electron donor (sole carbon) source for bacterial molybdate reduction to colloidal molybdenum blue (Mo-blue) was tested in this strain. A slight modification of the method of Ghani et al. [8] was used to prepare low phosphate-molybdate medium (LPM) containing in a litre of distilled water, $3 \mathrm{~g}\left(\mathrm{NH}_{4}\right)_{2} \mathrm{SO}_{4}, 0.5 \mathrm{~g} \mathrm{MgSO}_{4} .7 \mathrm{H}_{2} \mathrm{O}, 5 \mathrm{~g}$ $\mathrm{NaCl}, 2.42 \mathrm{~g} \mathrm{Na}_{2} \mathrm{MoO}_{4} .2 \mathrm{H}_{2} \mathrm{O}, 0.71 \mathrm{~g} \mathrm{Na}_{2} \mathrm{HPO}_{4}, 0.5 \mathrm{~g}$ yeast extract and $1.0 \mathrm{~g}$ cypermethrin (with glucose as control) were dissolved and the medium was adjusted to $\mathrm{pH} 7.0$ prior to autoclaving at $121{ }^{\circ} \mathrm{C}, 115 \mathrm{kPa}$ for $15 \mathrm{~min}$. Cypermethrin was separately autoclaved and added to the medium afterwards.

\section{Statistical Analysis}

Data are expressed as mean \pm SD of triplicate determinations, differences between means were analyzed via one way ANOVA with Turkey's post hoc using INSTAT GraphPad v 3.10 statistical software. 


\section{RESULTS AND DISCUSSION}

\section{Screening of Cypermethrin-Degrading Bacterium}

Several previously isolated and cultured bacterial strains were screened for their ability to use cypermethrin as the sole carbon and energy source. The result shows that Morganella sp. had the best cypermethrin-degrading potential by exhibiting higher tolerance to cypermethrin and faster growth in the MSM supplemented with cypermethrin $(1000 \mathrm{mg} / \mathrm{L})$ on agar plates for $48 \mathrm{~h}$ of incubation at $37^{\circ} \mathrm{C}$ and $\mathrm{pH} 7$ (Table 1). Thus, the strain was selected for characterization work. Furthermore, this is the first report on bacterial cypermethrin degradation from Nigeria, and perhaps from the genus Morganella.

Table 1. Screening of cypermethrin-degrading bacteria from isolated molybdenum-reducing cultures.

\begin{tabular}{ll}
\hline Isolates & $\begin{array}{l}\text { Colony count } \\
(\mathrm{CFU} / \mathrm{ml})\end{array}$ \\
\hline $\mathrm{A}$ & 170 \\
$\mathrm{~B}$ & 150 \\
$\mathrm{C}$ & 94 \\
$\mathrm{D}$ & 120 \\
$\mathrm{E}$ & 170 \\
$\mathrm{~F}$ & 142 \\
$\mathrm{G}$ & 36
\end{tabular}

\section{Effect of Incubation Time on Cypermethrin Degradation in} MSM

Cypermethrin degradation by Morganella sp. at different incubation periods was evaluated within $0 \mathrm{~h}-72 \mathrm{~h}$ at $24 \mathrm{~h}$ interval. The optimum incubation period was found to be at $24 \mathrm{~h}$ (Fig. 1), with a significant decrease in the bacterial growth and activity observed after $24 \mathrm{~h}$ of incubation. This is possible as a result of nutrient depletion and an increase in the number of cells overweighing that of the living cells, due to the metabolic activities occurring in the medium.

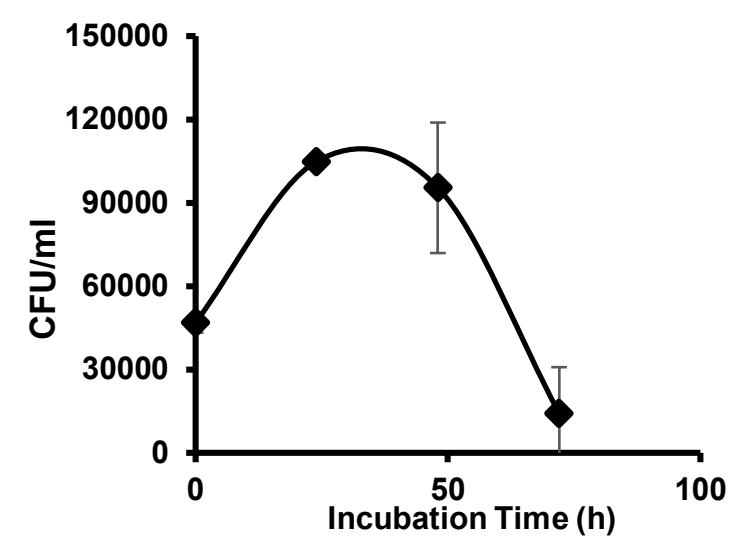

Fig. 1. Effect of incubation time on cypermethrin degradation by Morganella sp. Data represents mean \pm standard deviation of triplicates.

\section{Effect of Inoculum Size}

Inoculum size is an important factor that influences bacterial degradation activity, as appropriate cells volume facilitates the rate of degradation of cypermethrin. In this study, cypermethrin degradation by Morganella sp. was inoculated ranging from 50 $800 \mu \mathrm{L}$. The result (Figs. 2 and 3) indicated that as the inoculum size increases, the growth and degradation also increase until the optimum was attained at $400 \mu \mathrm{L}$. However, a significant decrease in growth was observed at inoculum size higher than $400 \mu \mathrm{L}$ following $24 \mathrm{~h}$ incubation at $35^{\circ} \mathrm{C}$ and $\mathrm{pH}$. This could be due to competition for the limited nutrient and antagonistic inhibition by metabolic substances that are synthesized by the indigenous microorganism [10].
Furthermore, the effect of various inoculum sizes over time shows that the growth and degradation of cypermethrin were optimum at $24 \mathrm{~h}$ of incubation in most of the tested inoculum, except for 200 and $800 \mu \mathrm{L}$ inoculum sizes which revealed a linearized growth pattern rather than the usual dome-belled shaped, and with no significant difference $(\mathrm{p}<0.05)$ between all the inoculum tested.

A higher initial inoculum could compensate for the initial population decline and survivors could multiply and degrade cypermethrin. Another possible reason for enhanced degradation with the increase of inoculum amount could be due to the fact that the survival microorganisms might use dead microbial structures as a source of the nutrient.

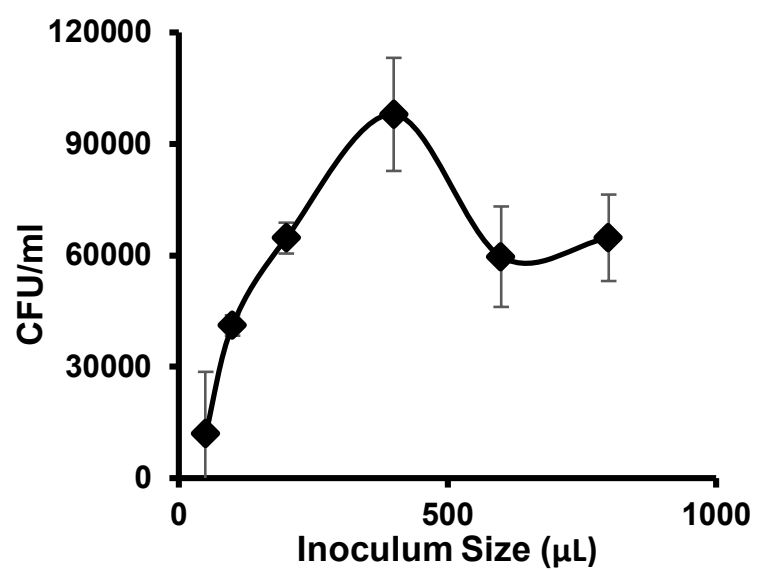

Fig. 2. Effect of inoculum size on cypermethrin degradation potential of Morganella sp. after $24 \mathrm{~h}$ incubation. Data represents mean \pm standard deviation of triplicates.

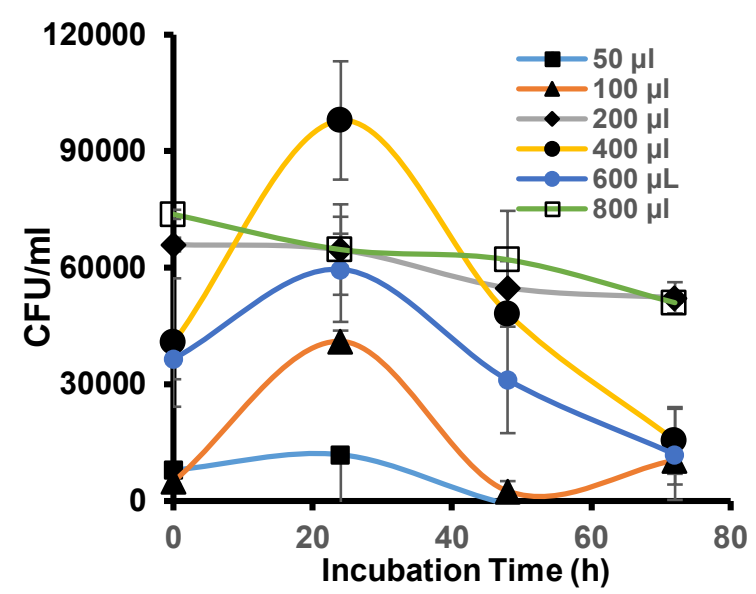

Fig. 3. Effect of various inoculum size on cypermethrin degradation rate by Morganella sp. Data represents mean \pm standard deviation of triplicate.

\section{Effect of Cypermethrin Concentration as carbon Source}

The carbon source introduced into a bacterial growth medium serves as the microorganism's chief source of nutrients and energy required for its metabolic activities, growth and survival. Thus, it is important to study the optimum carbon source concentration that enhances the degradation activity of the bacteria. The effect of cypermethrin concentration as the sole carbon source on its degradation was tested at concentrations ranging from 1000 to $5000 \mathrm{mg} / \mathrm{L}$. The results (Figs. 4 and 5) showed the optimum cypermethrin concentration to be at 4000 $\mathrm{mg} / \mathrm{L}$ with a significant increase and decrease $(\mathrm{p}<0.05)$ above $1000 \mathrm{mg} / \mathrm{L}$ and $4000 \mathrm{mg} / \mathrm{L}$ respectively after $24 \mathrm{~h}$ incubation at 
$37^{\circ} \mathrm{C}, \mathrm{pH}$ 7. Morganella sp. was found to optimally utilize 4000 $\mathrm{mg} / \mathrm{L}$ as its sole carbon source which contradicts the findings of Tallur et al. [9]; Akbar et al. [10] that reported $1000 \mathrm{mg} / \mathrm{L}$ and $100 \mathrm{mg} / \mathrm{L}$ as optimum respectively. This shows that a more cypermethrin-tolerant bacterium has been isolated, which may be attributed to the inherent characteristics of the soil from which the bacteria was isolated.

At low cypermethrin concentration, the rate of microbial activity was faster compared to the higher concentrations, which might be due to the toxicity of the cypermethrin that occurs at higher doses. Similarly, the fact that microbial growth and degradation starts slowly (lag phase) and requires acclimatization in the medium before the rapid degradation occurs at higher concentrations.

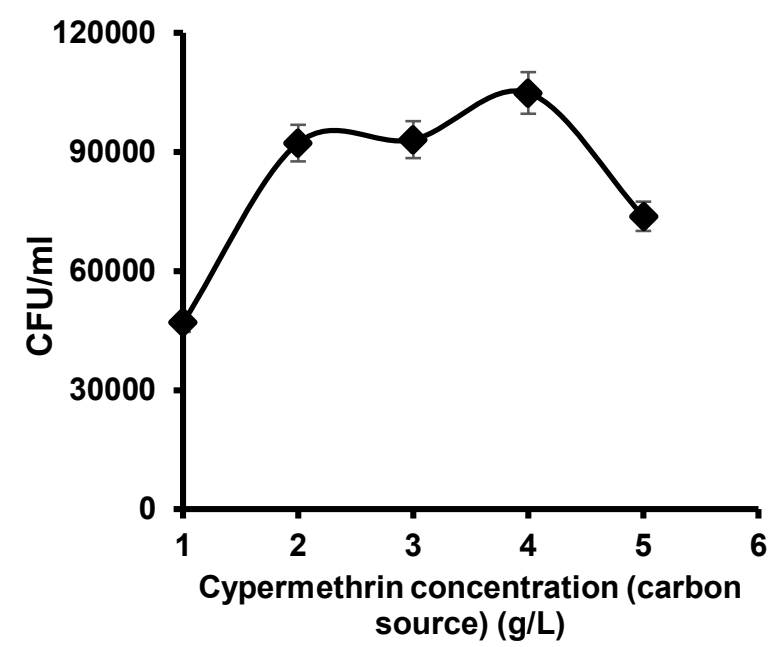

Fig. 4. Effect of cypermethrin concentration as sole carbon source on cypermethrin degradation potential of Morganella sp. after $24 \mathrm{~h}$ incubation. Data represents mean \pm standard deviation of triplicates.

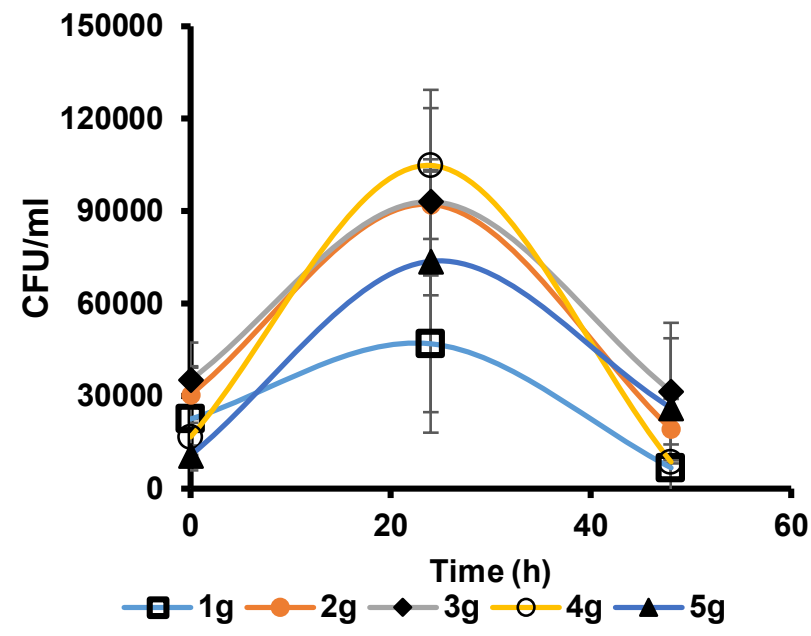

Fig. 5. Effect of various cypermethrin concentration on cypermethrin degradation rate by Morganella $\mathrm{sp}$. Data represents mean \pm standard deviation of triplicates.

\section{Effect of initial pH on Cypermethrin Degradation}

The $\mathrm{pH}$ is the measure of the alkalinity or acidity of a medium. It is an important factor that significantly affects microbial growth and their detoxification ability [12]. Microorganisms have $\mathrm{pH}$ at which they attain optimum degradation, the result of this study (Figs. 6 and 7) reveals that Morganella sp. was able to degrade cypermethrin over a $\mathrm{pH}$ range. However, the optimum $\mathrm{pH}$ for the degradation of cypermethrin by Morganella sp. was $\mathrm{pH} 7.5$ with a significant decrease $(\mathrm{p}<0.05)$ at $\mathrm{pH}$ below or above 7.5. Similar results were reported by Zhang et al. [13] who reported efficiently rapid cypermethrin degradation by two Serratia sp. at high $\mathrm{pH}$ while it was relatively low at acidic $\mathrm{pH}$ conditions. Relatedly, the results indicated that the degradation of cypermethrin was liable to happen at neutral and alkaline conditions. It may be due to the fact that acidic conditions increased cypermethrin stability and its resistance to chemical microbial degradation [11]. Another possible reason for the reduction in cypermethrin degradation in lower $\mathrm{pH}$ is that the acidic conditions may decrease the activity of the enzyme(s) involved in cypermethrin degradation [11].

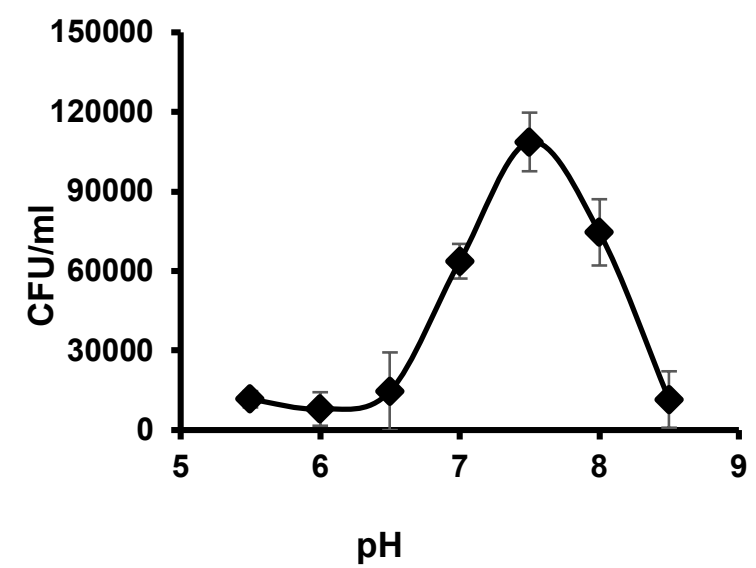

Fig. 6. Effect of $\mathrm{pH}$ on cypermethrin degradation by Morganella sp. after $24 \mathrm{~h}$ incubation. Data represents mean \pm standard deviation of triplicates.

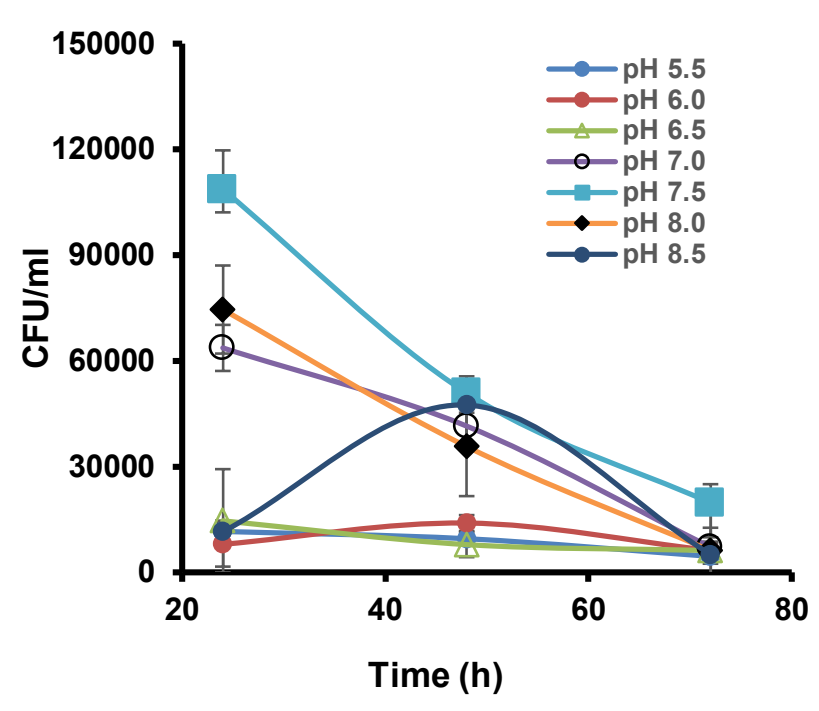

Fig. 7. Effect of various initial $\mathrm{pH}$ on cypermethrin degradation rate by Morganella sp. Data represents mean \pm standard deviation of triplicate.

\section{Effect of Temperature}

Temperature is the measure of the degree of hotness or coldness. It is an important parameter for microbial growth and activity. The effect of temperature on cypermethrin degradation by Morganella sp. during incubation temperatures ranging from 25 $-45^{\circ} \mathrm{C}$. After incubation for $24 \mathrm{~h}$ the best temperature for the degradation was found to be at $40{ }^{\circ} \mathrm{C}$ (Figs. 8 and 9) with a significant decrease $(\mathrm{p}<0.05)$ in degradation when compared to 
the degradation activity at $25,30,35$ and $45^{\circ} \mathrm{C}$. This finding deviated from those previously reported by [15-17]. This is possible because those reports were from degradation activities in the regions with very cold temperatures and while Morganella $\mathrm{sp}$. was isolated from the temperate region.

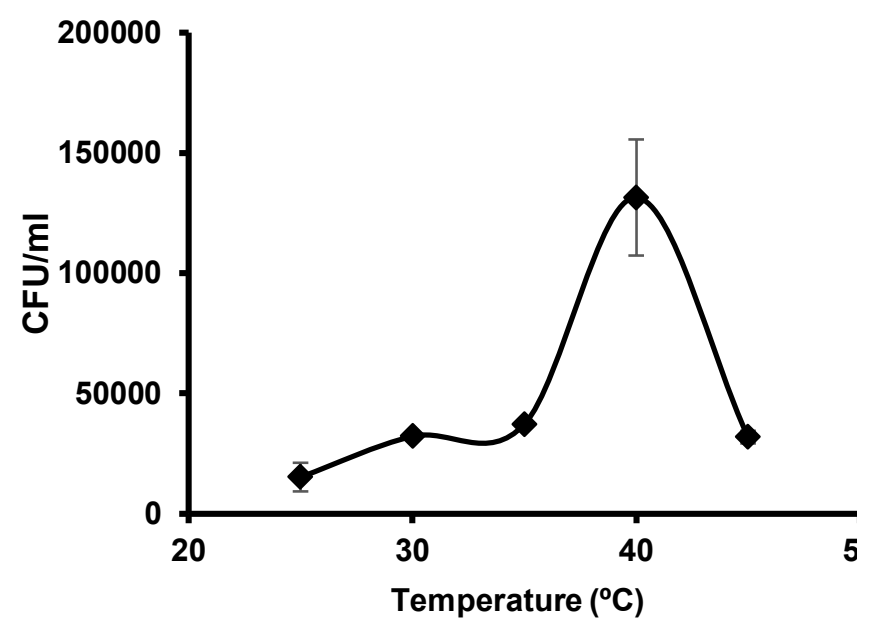

Fig. 8. Effect of temperature on the cypermethrin degradation by Morganella sp. after $24 \mathrm{~h}$ incubation. Data represents mean \pm standard deviation of triplicates.

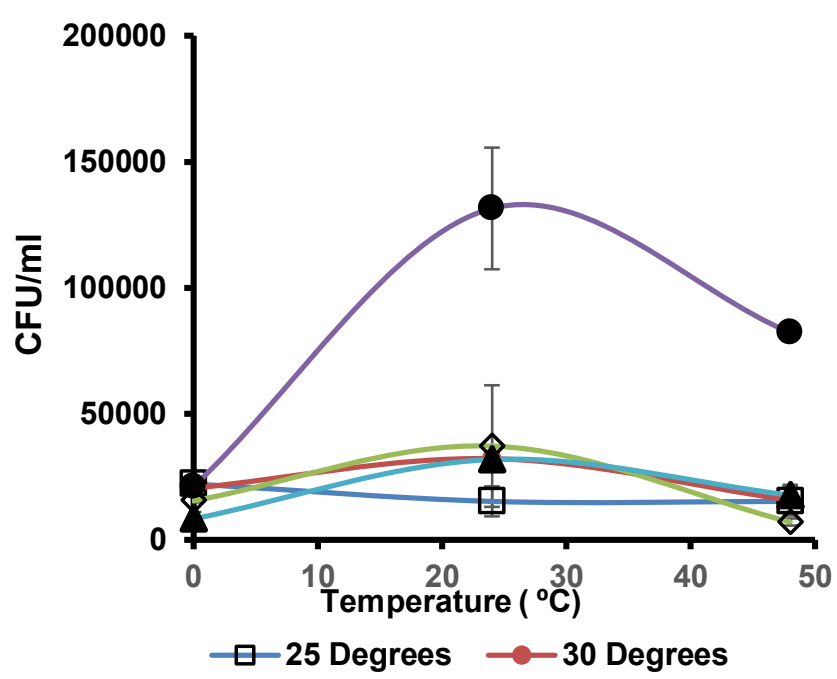

Fig. 9. Effect of temperatures on cypermethrin degradation rate potential of Morganella sp. after $24 \mathrm{~h}$ incubation. Data represents mean \pm standard deviation of triplicates.

\section{Effect of Interacting Heavy Metals}

Heavy metals are essential for microorganisms because they are utilized as a trace element. However, some heavy metals can become toxic for microorganisms at higher concentrations. Six heavy metal salts mercury oxide, zinc oxide, copper oxide, ferrous chloride, lead oxide, and silver nitrate were used for this study (Fig. 10) $\mathrm{Cu}, \mathrm{Zn}, \mathrm{Fe}$ and $\mathrm{Pb}$ have been seen to exert a significant inhibitory effect $(\mathrm{p}<0.05)$ on the degradation of cypermethrin, while Ag has the least significant inhibitory effect on the cypermethrin degrading potential of Morganella sp.
The tolerance level of Morganella sp. to Ag on cypermethrin degradation was further evaluated by varying the concentrations of $\mathrm{Ag}(1-10 \mathrm{ppm})$. The result (Fig. 11) showed a significant inhibition $(p<0.05)$ relative to the control. Heavy metal contamination of soils is widespread and may influence pesticide degradation [18]. Metal presence may inhibit the degradation of organic pollutants by exogenously added microorganisms [19]. In such cases it would be of advantage to add metal-resistant bacteria to the site, to protect the metal resistant pollutant degrading bacteria from metal toxicity [20].

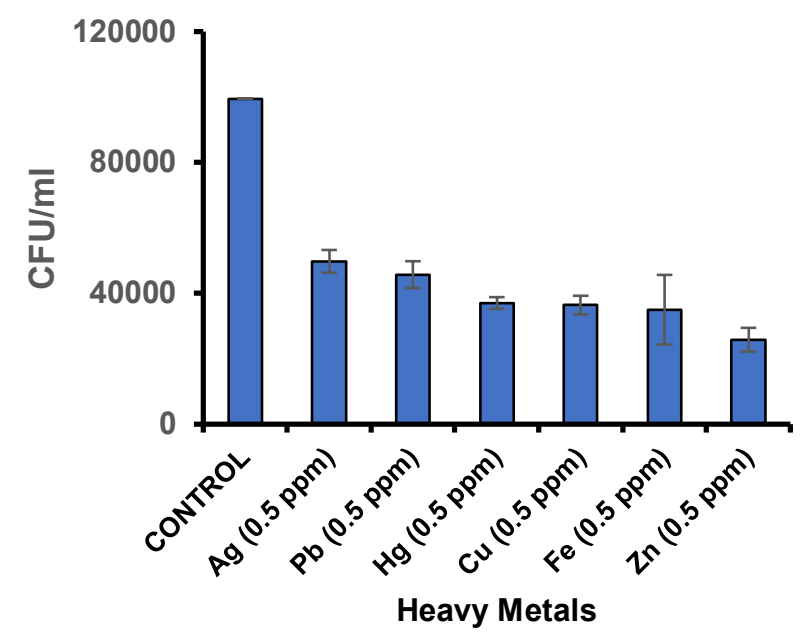

Fig. 10. Effect of interacting heavy metals $(0.5 \mathrm{ppm})$ on cypermethrin degradation by Morganella sp. Data represents mean \pm standard deviation of triplicates.

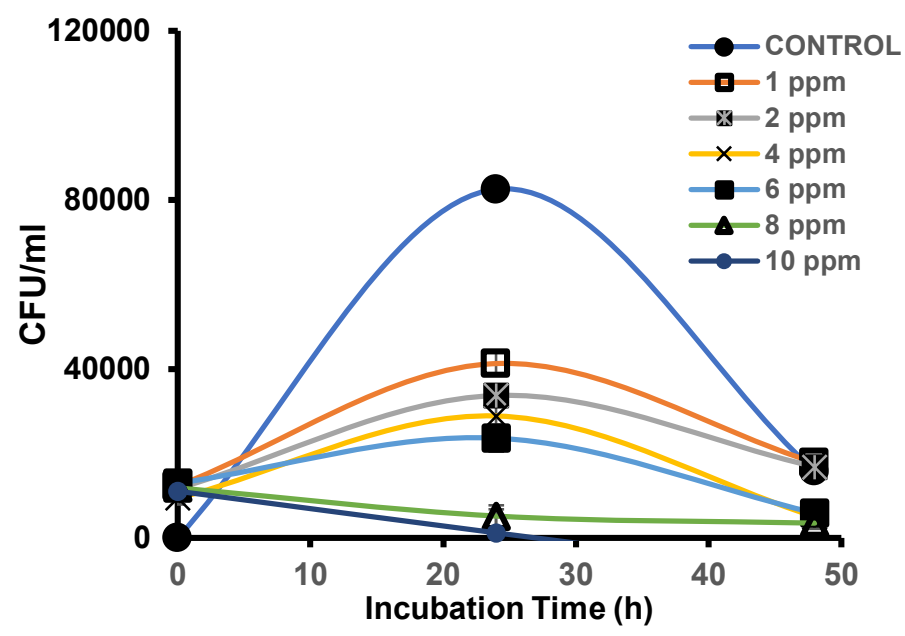

Fig. 11. Effect of various Ag concentrations on cypermethrin degradation rate by Morganella sp.

\section{Effect of Shaking}

The degradation of cypermethrin was subjected to agitation and aeration on an orbital shaker incubator at $160 \mathrm{rpm}$ for $24 \mathrm{~h}$, the result was compared to that of the experiment incubated in a static incubator which revealed that agitation and aeration enhanced the microbial degradation cypermethrin as shown in Table 2. Interestingly, the fact that agitation and aeration enhance the degradation activity of this bacterium could possibly reflect that the isolate is an aerobic microorganism. 
Table 2. Effect of shaking incubation on cypermethrin degradation by Morganella sp.

\begin{tabular}{|c|c|c|c|}
\hline $\begin{array}{l}\text { Incubation } \\
\text { Time (h) }\end{array}$ & 0 & 6 & 24 \\
\hline $\begin{array}{l}\text { Shaking } \\
\text { Incubation }\end{array}$ & $17647.27 \pm 3486.52$ & $50477.56 \pm 7222.86^{\mathrm{a}}$ & $24801.57 \pm 5246.48^{b}$ \\
\hline $\begin{array}{l}\text { Static } \\
\text { Incubation }\end{array}$ & $17647.27 \pm 3486.52$ & $21860.36 \pm 1075.35^{\mathrm{a}}$ & $72576.39 \pm 14424.06^{b}$ \\
\hline
\end{tabular}

\section{Screening of cypermethrin as a carbon source for molybdenum reduction}

The potential of cypermethrin serving as a carbon source for molybdenum reduction the results showed that it can be used as a carbon source for molybdenum reduction. However, glucose is a more suitable carbon source for molybdenum bioremediation. ANOVA analysis showed that there is a significant difference between glucose as a carbon source and cypermethrin $(\mathrm{p}<0.05)$ (Fig. 12). This is an added advantage to solving the environmental pollution caused by cypermethrin and the same that of molybdenum.

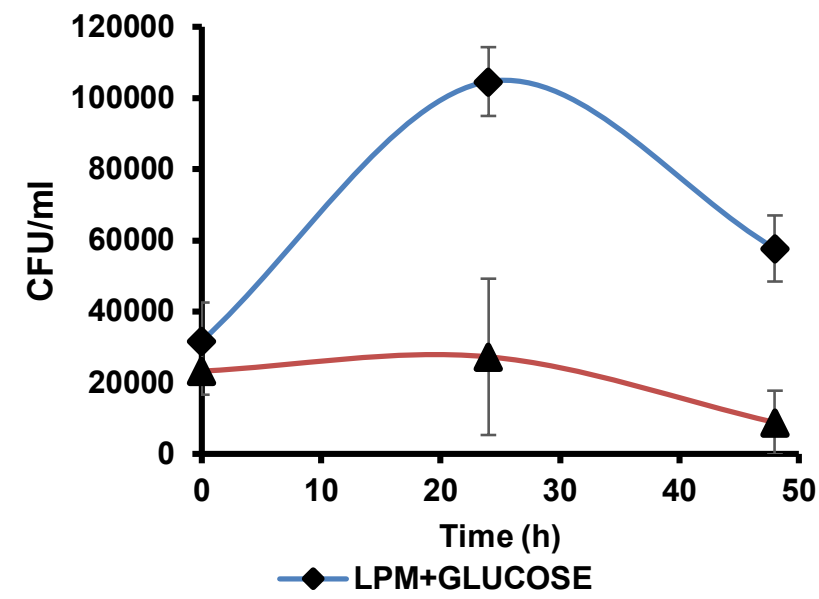

Fig. 12. Screening of cypermethrin as a carbon source for molybdenum reduction. Data represents mean \pm standard deviation of triplicates.

\section{CONCLUSION}

A bacterium with the ability to degrade cypermethrin has been characterized, this study revealed that Morganella sp. has the potential to optimally utilize $4 \mathrm{~g} / \mathrm{L}$ of cypermethrin as a sole carbon and energy source under $24 \mathrm{~h}$ of incubation at a $\mathrm{pH} 7.5$ and temperature $40^{\circ} \mathrm{C}$. The rate of degradation of cypermethrin by Morganella sp. was stimulated when the growth media was subjected to aeration and mechanical agitation, the rate of degradation was optimally stimulated at an inoculum size of 400 $\mu \mathrm{L}$. The heavy metal tolerance of Morganella sp. to $\mathrm{Ag}, \mathrm{Pb}$ and Fe would be of advantage for its better survival in cypermethrin contaminated sites co-contaminated by these heavy metals. Hence, this isolate could be a better candidate for future bioremediation of cypermethrin.

\section{REFERENCES}

1. Lin QS, Chen SH, Hu MY, Ul Haq MR, Yang L \& Li H. Biodegradation of cypermethrin by a newly isolated actinomycetes HU-s-01 from wastewater sludge. Int J Environ Sci Technol. 2011;1:45-56.
2. Chen $\mathrm{S}$, Geng $\mathrm{P}$, Xiao $\mathrm{Y} \& \mathrm{Hu} \mathrm{M}$. Bioremediation of $\beta$ cypermethrin and 3-phenoxybenzaldehyde contaminated soils using streptomyces aureus HP-S-01. Appl Microbiol Biotechnol. 2012a; 94(2):505-515.

3. Chen S, Luo J \& Hu M. Enhancement of cypermethrin degradation by a coculture of Bacillus cereus ZH-3 and Streptomyces aureus HP-S-01. Bioresour Technol, 2012b;110:97-104.

4. Chen S, Hu W, Xiao Y, Deng Y, Jia J. \& Hu M. Degradation of 3 Phenoxybenzoic Acid by a Bacillus sp. PLoS ONE, 2012c;7:10-11.

5. Meeker JD, Barr DB. \& Hauser R. Pyrethroid insecticide metabolites are associated with serum hormone levels in adult men. Reprod Toxicol, 2009;27(2):155-160.

6. Weston DP, Holmes RW. \& Lydy MJ. (2009). Residential runoff as a source of pyrethroid pesticides to urban creeks Pyrethroid insecticides regularly detected in residential runoff at toxicologically significant concentrations. Environ Poll, 2009;157:287-294.

7. Yin LB, Zhao LZ, Liu Y, Zhang DY, Zhang SB \& Xiao K. Isolation and characterization of cypermethrin degrading bacteria screened from contaminated soil. Biodegradation of hazardous and special products. Int Technol, 2013;2:1-16.

8. Ghani B, Takai M, Hisham NZ, Kishimoto N, Ismail AKM, Tano $\mathrm{T} \&$ Sugio, T. Isolation and characterization of a Mo6+-reducing bacterium. Appl Environ Microbiol, 1993;59:1176-1180.

9. Tallur PN, Mulla SI, Megadi VB, Talwar MP. \& Ninnekar HZ. Biodegradation of cypermethrin by immobilized cells of Micrococcus sp . strain CPN 1. Brazillian J Microbiol, 2015;46(3):667-672

10 Akbar S, Sultan S \& Kertesz M. Determination of Cypermethrin Degradation Potential of Soil Bacteria Along with Plant GrowthPromoting Characteristics. Curr Microbiol, 2014;43(2):1-10

11 Cycoń M, Żmijowska A. \& Piotrowska-Seget Z. Enhancement of deltamethrin degradation by soil bioaugmentation with two different strains of Serratia marcescens. Int J Environ Sci Technol, 2014;11(5):1305-1316.

12. Rowland SJ, Jones D, Scarlett AG, West CE, Pok L, Boberek M, Tonkin A, Smith BE \& Whitby C. Synthesis and toxicity of some metabolites of the microbial degradation of synthetic naphthenic acids. Sci Total Environ, 2011;409:2936-2941.

13. Zhang C, Wang S. \&Yan Y. (2011). Isomerization and biodegradation of beta-cypermethrin by Pseudomonas aeruginosa $\mathrm{CH} 7$ with biosurfactant production. Bioresour Technol, 102(14):7139-7146.

14. Cycon' M, Wojcik M \& Piotrowska-Seget Z. Biodegradation kinetics of the benzimidazole fungicide thiophanate-methyl by bacteria isolated from loamy sand soil. Biodegradation, 2011;22, 573-583.

15. Tiwary M \& Dubey AK. Cypermethrin bioremediation in presence of heavy metals by a novel heavy metal tolerant strain, Bacillus sp. AKD1. Int Biodeterior Biodegrad, 2016;108:42-47.

16. Xiao Y, Chen S, Gao Y, Hu W, Hu M \& Zhong G. Isolation of a novel beta-cypermethrin degrading strain Bacillus subtilis BSF01 and its biodegradation pathway. Appl Microbiol Biotechnol, 2015;99(6):2849-2859

17. Zhang C, Jia L, Wang S, Qu J, Li K, Xu L \& Yan Y. Biodegradation of beta-cypermethrin by two Serratia spp. with different cell surface hydrophobicity. Bioresour Technol, 2010;101(10): 34233429.

18. Bardos P. Composting of Mechanically Segregated Fractions of Municipal Solid Waste. A Review In SITA Enironmental Trust, 2004;30:1-143.

19. Megharaj M, Ramakrishnan B, Venkateswarlu K, Sethunathan N \& Naidu R. Bioremediation approaches for organic pollutants: A critical perspective. Environ Int, 2011;37:1362-1375.

20. Fernandez JM, Senesi N, Plaza C, Brunetti G \& Polo A. Effects of composted and thermally dried sludges on soil and soil humic acid properties. Environ Poll, 2009;19:281-291. 